\title{
Os estudos sobre a hipótese de agendamento
}

ENTRE OSAN OS 20E OSANOS 70, desenvolveramse um sem-número de teorias ligadas aos processos de comunicação que podem ser agrupadas, genericamente, em vários blocos, comosugereMauroWolf: ${ }^{1}$ teoriahipodérmica ou de manipulação, teorias empíricas de campo e experimentais, também denominadas de persuasão, teoria funcionalista, teoria estruturalista, teoria crítica - mais conhecida como da Escola de Frankfurt,com todos os seus desdobramentos - teorias culturológicas, cultural studies, teorias comunicativas (a teoria matemática, a semiótica em sentido estrito, devido a Umberto Eco, e as lingüísticas), etc.

Havia, de modo geral, um enorme fosso a separar esseconjunto deteorias em relação as suasfontes, os paradigmas norte-americanos, essencial mente descritivistas e burocráticos, segundo alguns, e os paradigmas europeus, essencialmentesociológicoseexcessivamente ideológicos, segundo seus críticos norteamericanos.

Em ambos os casos, contudo, havia, em comum, o aspecto negativo que caracteriza toda e qualquer teoria: por ser um sistema fechado, ela é excludente. Assim, assumir uma determinada linha de pesquisa significava, por conseqüência, eliminar toda e qual quer outra alternativa.

Foi então que, a partir do final dos anos 60, concentrando-senos anos 70 , surgiram o que hojesecostumadenominar decommunication research, nos Estados Unidos, publicística, na Alemanha e na Itália, ou midiologia na França, ${ }^{2}$ através de diferentes pesquisadores que, não apenas se propunham a atuar em equipe, quanto buscavam o cruzamento das diferentes teorias e, muito especialmente, de múltiplas disciplinas, a fim de compreender 
do processo comunicacional.

Foi o que aconteceu com o norte-americano Maxwell McCombs, aalemãElisabeth N oelleNeumann ou o francês Régis Debray, responsáveis, respectivamente, por áreas de pesquisa hoje mundialmente conhecidas como agenda-setting, espiral do silêncio e midiologia , isso, para não esquecermos outros caminhos alternativos como o chamado newsmaking que, na verdade, se não tem um autor específico responsável por seu desenvolvimento, nem por isso possui menor importância no conjunto de estudos em torno da comunicação, tais como hoje em dia se desenvolvem em todo o mundo.

Vamo-nos ater à linha de pesquisa denominada agenda-setting que, no Brasil, é a que tem encontrado maior repercussão, já alcançando alguns registros, quer em traduções, quer em obrasque, baseadas nesta pesquisa, buscam desenvolver reflexões a respeito dos processos comunicacionais em nosso país.

Registremos, antes demaisnada, queostextos damaioriadestaslinhas depesquisasãoraros em nosso idioma, e o material que encontramos, quandonão eminglês, acha-sepublicado em Portugal (caso de Mauro Wolf, obra mencionada) ou em espanhol, como no caso da hipótese da espiral do silêncio de NoelleNeumann. ${ }^{3}$ Quanto à midiologia, destacamse as traduções das obras de Régis Debray ${ }^{4}$ que, a partir de1994, foramlançadasno Brasil. Por fim, quanto ao newsmaking , é ainda o livro já citado de Mauro Wolf a única fonte que conheço. ${ }^{5}$

A hipótese de agenda-setting, ao contrário, estámaisdocumentadaemlínguaportuguesa. Encontramo-la, al ém do livro já mencionado de Mauro Wolf, cuja primeira edição é de 1987, na edição brasileira de Teorias da Comunicação de M assa, de Melvin L. De Fleur e Sandra Ball.Rokeach, refundição de umaobra original escrita pelo primeiroautor, apenas, em anos anteriores. ${ }^{6}$ Em pouco mais deuma página, DeFleur menciona a hipótese do agendamento que a mídia realiza junto ao receptor, formuladaa partir do final dos anos 60 , pelos professores Maxwell E. McCombse Donald L. Shaw.

Comecemos por esclarecer por que falamos em "hipótese" e não em "teoria", simplesmente. Ora, antes de mais nada, porque uma teoria, como enfatizei anteriormente, é um paradigma fechado, um modo "acabado" e, nestesentido, infenso a complementações ou conjugações, pela qual "traduzimos"uma determinada realidade segundo um certo "modelo". Uma "hipótese", ao contrário, é umsistemaaberto, sempreinacabado, infenso ao conceito de "erro" característico de uma teoria. Assim, a uma hipótese não se pode jamais agregar um adjetivo que caracterize uma falha: uma hipótese é sempre uma experiência, um caminho a ser comprovadoe que, seeventualmentenão "der certo" naquela situação específica, não invalida necessariamentea perspectivateórica. Pelo contrário, levanta, automaticamente, o pressuposto alternativo de que uma outra variante, não presumida, cruzou pela hipótese empírica, fazendo com que, na experiência concretizada, elanão seconfirmasse. Aliás, podesetomar, na própria aplicação da hipótesedo agendamento, um estudo, hoje referencial, de GladysEngel LangeKurtLang, quebuscaram aplicar o princípio do agendamento à situação histórica do episódio de Watergate, nos Estados Unidos. A questão que os pesquisadores se colocavam era essa: se a hipótese deagendamento éviável, como explicar que, apesar de todo o conjunto de denúncias desenvolvidas por The W ashington Post, ao longo de 1972, o então Presidente Richard Nixon chegassea sereel eger com percentuais altamente significativos para sofrer um processo de impeachment pouco tempo depois, o que o levaria à renúncia, a fim de não ser derrubado do Poder pelo Congresso? ${ }^{7}$

Os pressupostos da hipótese de agendamento são vários, mas destaquemos alguns principais: 
a) ofluxo contínuo deinformação: verifica-se que o processo de informação e de comunicação não é, como parecem pressupor as antigas teorias, um processo fechado. $\mathrm{Na}$ verdade, as teorias clássicas como quefazem um recorte, fragmentando a realidade, talvez com intuitos didáticos, quanto aos processos comunicacionais. Damanhãànoite, contudo, sofremosverdadeiraavalancheinformacional que, na maioria das vezes inclusive, nos leva ao conhecido processo de entropia, ou seja, um excesso de informações que, não trabalhadas devidamente pelo receptor, se perdem ou geram situações inusitadas como aquelasjáflagradasnoengraçadíssimoSamba do Crioulo doido de Stanislaw Ponte Preta. O que, na verdade, ocorre, é que este fluxo contínuo informacional gerao queMcCombs denominará de efeito de enciclopédia que podeser inclusive concretamenteprovocado pela mídia, semprequeisso interesse, através de procedimentos técnicos como o chamado box que revistas e jornais muitas vezes estampam junto a uma grande reportagem, visando atualizar o leitor em torno de determinado fato. Na maioria dos casos, contudo, consciente ou inconscientemente, guardamos de maneira imperceptível em nossa memória uma série de informações de que, repentinamente, lançamos mão. É assim que se pode explicar, por exemplo, a reação provocada pela série de episódios em torno do ex-PresidenteCollor deM ello, sem o que, talvez, repetiríamos a experiência de Watergate, sem termos jamais chegado à cassação do antigo mandatário nacional;

b) os meios de comunicação, por conseqüência, influenciam sobre o receptor não a curto prazo, como boapartedasantigasteorias pressupunham, mas sim a médio e longo prazos. Ou seja, é mediante a observação de períodos de tempo mais longos do que os habitualmente até então configurados que podemos aquilatar,com maior precisão, os efeitos provocados pelos meios de comunicação. Maisqueisso, deve-selevar emconta não apenas o lapso de tempo abrangido por uma determinada cobertura jornalística quanto, muito especialmente, o tempo decorrido entre esta publicidade e a concretização de seus efeitos em termos de uma ação conseqüentepor partedo receptor. Tomese o exemplo ainda recente da criação do Plano Real e o posterior lançamento do exMinistro do Planejamento Fernando Henrique Cardoso como candidato à Presidência da República, com o resultado eleitoral que todos conhecemos: enquanto que em maio daquele ano eleitoral, Luís Inácio Lula da Silva era considerado virtual candidato preferencial, com mais da metade das intenções de voto, em pouco mais de cinco meses, revertia-sea situação, com a vitória de Fernando Henrique, em outubro, ainda em primeiro turno, o que significava, em termos do sistema eleitoral brasileiro, ter al cançado mais que a metade dos votos válidos para aquela eleição. Ora, éevidentequehouveum efeito de enciclopédia propositadamente buscado por parte dos responsáveis pela campanhadeFernando Henrique, vinculando o candidato à nova moeda e a seu sucesso enquanto determinadora do controle inflacionário brasileiro, num processo que, em médio prazo (cinco meses), minou significativamente o discurso de oposição (independentemente de que se analise os equívocos de avaliação que apostaram no desastre do Plano ou na sua falência póseleitoral);

c) osmeios decomunicação, emboranão sejam capazes de impor o que pensar em relação a um determinadotema, como desejavaateoria hipodérmica, são capazes de, a médio elongo prazo, influenciar sobre o que pensar e falar, o que motiva o batismo desta hipótese de trabalho. Ou seja, dependendo dos assuntos que venham a ser abordados - agendados pela mídia , o público termina, a médio e longo prazos, por incluí-los igualmente em suas preocupações. Assim, a agenda da mídia termina por se constituir também na agenda individual e mesmo na agenda social .

As bases teóricas desta hipótese de pesquisa são bastante antigas. Podemos baseá-las na 
obradeGabriel Tardesobreaopinião pública, 8 se quisermos expandir um pouco mais a pesquisaforadasfronteirasnorte-americanas, onde ela se estruturou, ou no livro deWalter Lippmann sobre o mesmo tema. ${ }^{9}$

ParaLippmann, nossarelação comarealidade não se dá de maneira direta. Ou melhor, emboraelaocorrademododireto, a percepção quedelatemosnãoédireta, massim mediada por "imagensqueformamosemnossamente". Desta forma, percebemos a realidade não enquanto tal, mas sim enquanto a imaginamos.

Ora, desde o século passado, graças, dentre outros, a Ferdinand Tönnies, ${ }^{10}$ conhecemos a diferença entre as chamadas gemeinschaften e as gesellschaften, ou seja, sociedades comunitárias e sociedades anônimas. As primeiras estão ligadas às civilizações primitivas, emqueasrelaçõessedesenvolvem demaneiradireta, em quetodos seconhecem entre si eem que todo o fluxo informacional é absolutamente personalizado. Nas sociedades anônimas, contudo, fruto da urbanização, os processos demassificação setornam necessários, uma vez que a maioria dos integrantes de tais sociedades não pode ter acesso direto aos acontecimentos. Assim é que surgem os chamados meios de comunicação de massa ou, como os americanos denominam, os mass media, constituídos pelos jornais, revistas, emissoras de rádios, cadeias detel evisão e, a cada dia mais, outras redes, dentreas quais,contemporaneamente, a Internet.

Assim, numa sociedade urbana complexa, temosnecessidadedamediação dosmeios de comunicação: não podemos ser testemunhas oculares das decisões do Palácio do Planalto ou do Congresso Nacional, ainda que, eventual mente, numa pequena comunidade, possamosassistir a uma reunião queculmine em determinadadecisão por partedo prefeito, chefe do Executivo municipal daquela comuna (contudo, como adventodo tel efone, inclusive dos celulares, as práticas del obbyng ganharam outra dimensão inimaginável até poucos anos atrás...).

Portanto, dependendo da mídia, sofremos sua influência, não a curto, mas a médio e longo prazos, não nosimpondo determinados conceitos, mas incluindo em nossas preocupações certos temas que, de outro modo, não chegariam a nosso conhecimento e, muito menos, tornar-se-iamtemasdenossaagenda.

Para configurar essa hipótese, o professor Maxwell McCombs, em 1968, fez um acompanhamento inicial da campanha eleitoral nacional dos Estados Unidos.

Um estudo exploratório foi desdobrado a partir da Universidade da Califórnia, na localidade de Chapell Hill, na Carolina do Norte.

Concretizado num curto prazo de 24 dias (entre 12 de setembro e 6 de outubro) que antecederam as eleições nacionais, o pesquisador esua equi petrabal haram com cerca de 100 (cem) questionários, selecionados na relação de eleitores, de maneira a cobrir um universo variado de posição econômicofinanceira, social eracial, dentre aqueles que se encontravam ainda indecisos quanto ao voto a ser dado, entre Hubert Humprey e Richard Nixon.

Para cotejar a agenda do público com a da mídia, fez-se uma seleção de cinco jornais, dois canais nacionais de televisão e duas revistas semanais.

Dos jornais, quatro eram regionais: $D$ urham $M$ orning $H$ erald, Durham Sun, Raleigh $N$ ews and $O$ bserver e Raleigh Times, e um nacional, o N ew Y ork Times; as duas revistas nacionais foram Time e N ewsweek, e os canais de televisão foram a NBC e a CBS, com seus noticiários noturnos nacionais. Os temas foram codificados em quinze diferentes categorias, agrupados, por seu lado, em três grandesblocos, denominadosTemas, Campanha e Candidatos: 


$\begin{array}{lll}\begin{array}{l}\text { Temas } \\ \begin{array}{l}\text { Política } \\ \text { Internacional }\end{array}\end{array} & \begin{array}{l}\text { Campanha } \\ \text { Eleições }\end{array} & \begin{array}{l}\text { Candidatos } \\ \text { Humphrey }\end{array} \\ \text { Política fiscalo } & \begin{array}{l}\text { Eventos de } \\ \text { campanha }\end{array} & \text { Muskie } \\ \text { campanha } & \text { Nixon } \\ \begin{array}{l}\text { Bem-estar } \\ \text { público }\end{array} & \text { Agnew } \\ \text { Direitos civis } & & \text { Wallace } \\ \text { Outros } & & \text { Lemay }\end{array}$

I gualmentetomou-seumcritério objetivopara a classificação das matérias divulgadas, de maneiraaseter um padrão comparativo entre os três tipos de mídia, classificando-se as matérias em maiores emenores, entendendose como maiores aquelas que:

a) nosjornais, aparecessem como chamadade capa (incluindo olead, ou seja, todo o primeiro parágrafo da matéria,comasquestõesiniciais do modelo tradicional do jornalismo norteamericano traduzidas nos conhecidos five W), matérias com três colunas nas páginas internas ou matérias em que pelo menos um mínimo de cinco parágrafos estivessem destinados ao tema eleitoral;

b) nas revistas, cobrissem pelo menos uma coluna de informação ou que aparecessem com destaque no lead ou abertura de al guma seção da revista;

c) nas televisões, alcançassem o tempo de pelo menos 45 segundos ou estivessem entre as três matérias de chamada da edição do noticiário daquela noite.

É evidenteque estes critérios foram tomados a partir dos paradigmas do jornalismo norteamericano, mascomo o jornalismo brasileiro, desdea décadade 5o, inspira-senestemesmo modelo, pode-seestendêlo igual mentecomo paradigma para um eventual estudo brasileiro, sem maiores problemas).

Verificou-se, então, queamídia, defato, havia provocado um forte impacto e influenciado significativamente o eleitor. A novidade, contudo, é que, mais do que influenciar o eleitor (em princípio, o receptor que estava sendo pesquisado), verificou-se que a mídia terminara por influenciar também aos próprioscandidatos, fazendo comquemuitos delesincluíssem em suas agendas temas que, inicialmente, não constavamdasmesmas, mas que, ou por terem sido abordados por seus concorrentes, ou porque foram agendados pela mídia, terminaram por ser considerados pelas agendas dos candidatos. ${ }^{11}$

Persistiam, contudo, muitas dúvidas para os pesquisadores, deformaqueem 1972, quando da nova campanha eleitoral, Maxwell McCombs aliou-se a Donald L. Shaw, para aprofundar o estudo. Já então, os dois pesquisadores haviam publicado um estudo preliminar. ${ }^{12} \mathrm{O}$ novo trabalho pretendia "refinar" ashipóteseslevantadase, paratanto, escolheu cinco pontos de concentração: a) definiçãodo conceito; b) fontes deinformação para a agenda pessoal; c) desenvolvimento temporal como variável maior; d) características pessoais do eleitor; e) política e agendamento.

Desta vez, escolheu-se a localidade de Charlotte Ville, na Carolina do Norte, cidade situada a meio caminho entre Washington D.C. (a capital federal) eA tlanta, na Georgia, com 354 mil habitantes. Se Chapell Hill era uma cidade pequenina, conservadora e isoladaemsi mesma, Charlotteeraexatamente o contrário: ninguém era dali originário, pois setratava deuma cidadeem plena expansão, com verdadeira explosão demográfica. Os moradores isolavam-se na maioria dos casos em apartamentos, eram oriundos dos mais variados pontos do país e isso se tornou inclusive um problema para o desenvolvimento da pesquisa, porque, a partir dos 
150 mil el eitores, escol heu-seumconjunto de 380 delesparaa pesquisa. No entanto, também o prazo de acompanhamento do trabalho foi ampliado, iniciando-seemjunhoeterminando apenasemoutubro, cobrindo pois, quasecinco meses, o queresultou na perda demuitos dos primeiros pesquisados, chegando-se ao número máximo de apenas 230 , porque boa partedestes 39\% iniciaissimplesmenteforamsemudando dacidadeno decorrer dosmeses. Paraequilibrar aquestão doseleitoresnegros, que haviam ficado em desvantagem neste conjunto inicial de pesquisa, os cientistas agregaram 41 novos pesquisados, dos quais 24 foram posteriormente considerados, fechando-seo resultado final comumtotal de 227 questionários convalidados, a partir do mesmo critério: apenas aqueles que de fato ainda se mantinham indecisos quanto ao candidato a ser escolhido, numa campanha forte em que Richard Nixon, concorrendo à reeleição, tinha em George McGovern seu principal adversário.

Quanto à primeira questão, em torno da própria conceituação da hipótese, verificouse que, à medida que a campanha avançava, a atenção dos eleitores amplia-se; mais que isso, os eleitores, através da mídia, passam a constituir um conjunto de informações mais ou menos comuns entre esta audiência; esse conjunto de informações produz a base para a formação de uma atitude ou uma mudança de atitude diante dos candidatos; por fim, esta atitude sociabiliza-se entre os diferentes membros de uma mesma comunidade. É evidentequeisso tem um fortereflexo para o resultado eleitoral final.

Quantoàquestão envolvendo aformação das agendas pessoais e as diferentes influências queelassofrem(alémdainfluênciadamídia), verificou-se claramente a importância do chamado duplo fluxo informacional, já conhecido desdeas antigas teorias empíricas experimentais dos anos trinta, segundo as quais a maior parte das informações não transita diretamente de uma mídia para o receptor, mas étambém mediada através dos chamados líderes de opinião, com os quais estabelecemos relações emocionais as mais variadas.

É tambémevidentequehámaneiras diversas de encarar uma mesma agenda, ou uma questão genérica pode receber conotações muito particulares. Foi o que se descobriu, por exemplo, quando, esmiuçando o tema Política internacional, que não tivera grande destaquena pesquisaanterior, desdobrandoseoitemem váriasquestõesmaisparticulares, de imediato a questão Guerra do V ietname, queera então um tema momentoso (edo qual Nixon tratavadeselivrar, urgentemente, quer para evitar o desastre de uma derrota, quer para cabalar votos, garantindo uma paz honrosa, iniciada com aquela famosa e inesperada primeira visita de um Presidente norte-americano à China de M ao Tsé-Tung, amplamente coberta pela mídia norteamericana, pouco antes de iniciada a campanha eleitoral), alcançou índices extremamente significativos, pelo simples fato de que, como severificava então, o eleitor norteamericano não entendera Guerra do V ietname como um tema da Política Internacional, até porque, para ele, levando-se em conta que a maioria das famílias norte-americanas tinha al guém em sua relação direta ou de amigos como soldado na guerra (quando não ferido ou morto), o problema era diverso, talvez de Política interna, não mencionada na primeira pesquisa. Assim, osestudiosos deram-seconta de que a precisão de um questionário pode evidenciar particularidades da agenda do receptor quequestõesmaisgeraisnão deixam perceber.

No quetocaàquestão daseqüênciatemporal, levando-se em conta que o agendamento se dá necessariamente no tempo, verificou-se que se estabel ece uma verdadeira correlação entrea agenda da mídia ea do receptor, mas também a agenda do receptor pode e acaba influenciando a agenda da mídia. Mais do queisso, descobriu-sequetambém haviaum interagendamento entre os diferentes tipos demídia, chegando-semesmo a perceber que 
amídiaimpressapossui certahierarquiasobre a mídia eletrônica, tanto no que toca ao agendamento do receptor em geral (pela sua maior permanência e poder de introjeção através da leitura) quanto sobre as demais mídias (que, por sua vez, evidenciam maior dinamicidadeeflexibilidade para expandir a informação e complementá-la). Estabelecese, desta maneira, uma espécie de suíte sui generis, em que um tipo de mídia vai agendando o outro (lembremos o episódio Collor de Mello, em que as revistas IstoÉ e $V$ eja terminaram por agendar literalmente as televisões e os jornais, ainda que tivessem apenasediçõessemanais, graçasàsentrevistas que alcançaram, com o motorista ou a secretária, capazes de trazer novos enfoques ao tema. Por outro lado, não se pode esquecer,ainda no mesmo episódio, que foi unânime a avaliação de tantos quanto acompanharam o caso que, não fosse a mídia nacional eo Congresso $\mathrm{N}$ acional jamais teria chegadoàdecisão quetomou, tendoencerrado o caso bem antes de ter qual quer conclusão sobre 0 assunto. Pode-se ainda relembrar episódio anterior quefoi oagendamento, pela opinião pública, da TV Globo, quando da chamadaD iretas Já, em queaquel a redetentou esquivar-se o quanto pode à cobertura do evento, masacabou rendendo-seà pressão do receptor edo restantedamídia, com destaque ao jornal Folha de São Paulo e ao noticiário noturno da TV Manchete).

Quantoàscaracterísticas pessoais do receptor e à formação de uma agenda, tudo depende dos graus de percepção da relevância ou importância do tema, além dos diferentes níveis de necessidade de orientação que, em torno daquele tema, observará o receptor. Assim, pode-se dizer que a percepção de relevância poderá ser alta, média ou baixa. Em sendo baixa, evidentemente o receptor não demonstrará nenhum grau de interesse em adquirir qualquer tipo deinformação em torno daquele tema. No entanto, se houver um nível médio de relevância ao assunto, haverá , em conseqüência, um interesse mínimo emaquisição deinformação sobretal acontecimento, ainda que seu reflexo em termos deagendamento seja, ainda, mínimo. O agendamentosomenteocorrerádemaneira eficiente quando houver um alto nível de percepção de relevância para o tema e, ao mesmo tempo, um grau deincertezarelativamenteal to em relação ao domínio do mesmo, levando o receptor a buscar informar-se com maior intensidadearespeitodaqueleassunto. Encontramo-nos, pois, ao nível de uma cognição racionalizada, considerada a mais altahierarquiano clássi co quadro constituído porWilburSchrammnumestudo conhecido ${ }^{13}$ (osdemaissão onível instintivoeoemocional).

Enfim, quanto à questão da pol ítica em si, no que toca ao agendamento, verificou-se que o políticoéextremamentesensível atal processo e, assim, emsociedadesem que, como anorteamericana, a atividade política é extremamente valorizada, ${ }^{14}$ a mídia alcança uma importância superior na constituição das relações políticas. O estudo de McCombs e Shaw, por exemplo, evidenciou que os eleitoresaumentavamabusca deinformações à medida que a campanha eleitoral se desenvolviaeaproximava-seadatadaeleição, o que podemos confirmar com absoluta facilidade acompanhando, por exemplo,no Brasil, a audiência aos chamados programas obrigatórios de nossas campanhas eleitorais; essa procura por informações contribui eficientemente para a definição do el eitor em relação aos temas que o levam a decidir-se pelo candidato a quem confiará seu voto e, conseqüentemente, influencia o próprio resultado eleitoral; cada mídia desenvolve um tipo diferenciado de influência, graças às especificidades queapresenta, mas o quefica bastante claro é que, graças a este envolvimento da mídia, e seu conseqüentemente agendamento, amplia-se também a comunicação fora do circuito estrito da mídia, isto é, as pessoas aumentam, no conjunto de suas relações sociais, as mais variadas, do círculo familiar aos amigos do clube ou aos companheiros de trabalho ou escola, a troca de opiniões e informações, dinamizando o processo informacional-comunicacional. 
Conclui-se, assim, que a influência do agendamento por parte da mídia depende, efetivamente, do grau de exposição a que o receptor esteja exposto, mas, mais que isso, do tipo de mídia, do grau de relevância e interessequeestereceptor venha a emprestar ao tema, a saliência que ele lhe reconhecer, sua necessidadedeorientação ou sua falta de informação,ou, ainda, seu grau de incerteza, além dos diferentes níveis de comunicação interpessoal que desenvolver.

Por ser uma hipótese de trabalho, como salientei, enão uma teoria fechada, diferentes experiências, extremamente ricas, têm-se desenvolvido neste campo sempre aberto a especulações. A partir dolivro queM cCombs e Shaw publicaram, ${ }^{15}$ multiplicaram-se os estudos, quer por outros pesquisadores, quer pelos próprios pioneiros,como o evidencia um texto mais recentede M axwell McCombs em que ele aprofunda questões como a exploração da informação, seus relatos , as imagens provocadas pela mídia e, enfim, a criação da opinião pública. ${ }^{16}$

Por outrolado, novashipóteses detrabal hose desenvolveram complementarmente a essa. Por exemplo, a antes mencionada Elisabeth N oelle-N eumann, ao constituir sua hipótese da espiral de silêncio, refere explicitamente a hipótese de agendamento na introdução de seu estudo, aliás, cujas pesquisas iniciaram contemporaneamenteaotrabal hodeM cCombs. No Brasil, Clóvis de Barros Filho tem sido o principal divulgador desses estudos, inicialmente em al guns papers isolados e agora em obra volumosa, ${ }^{17}$ aluno que foi do próprio autor desta pesquisa.

Há alguns conceitos básicos em torno deste estudo que, para encerrar, quero repassar para o leitor:

acumulação - capacidade quea mídia tem de dar relevância a um determinado tema, destacando-o doimenso conjunto deacontecimentos diários que serão transformados posteriormente em notícia e, por conse- qüência, em informação;

consonância - apesar de suas diferenças e especificidades, osmídias possuem traçosem comum e semel hanças na maneira pela qual atuam na transformação do relato de um acontecimento que se torna notícia. Conseqüentemente, al gunsprincípiosgeraispodem ser aplicados, independentemente de suas idiossincrasias;

onipresença - um acontecimento que, transformado em notícia, ultrapassa os espaços tradicional mentea eledeterminados setorna onipresente. Por exemplo, quando a página policial acaba por se ocupar de um assunto desportivo (o recente episódio envolvendo a corrupção de juízes por dirigentes de futebol);

relevância - ela é avaliada pela consonância do tema nos diferentes mídias, ou seja, seum determinado acontecimento acaba sendo noticiado por todos os diferentes mídias, independentementedoenfoquequelhevenha a ser dado, el e possui evidente rel evância;

frame temporal - quadro de informações que seformaaolongo deum determinadoperíodo de tempo da pesquisa e que nos permite a interpretação contextualizada do acontecimento; ele cobre todo o período de levantamento de dados das duas ou mais agendas (isto é, a agenda da mídia ea agenda dos receptores, por exemplo);

timelag - é o intervalo decorrente entre o período delevantamento daagenda da mídia e a agenda do receptor, isto é, como se pressupõe a existência de um efeito de influência da mídia sobre o receptor, el a não sedá mágica eimediatamente, mas necessita de um certo tempo para se efetivar e ser constatável. A este intervalo de tempo se denomina timelag;

centralidade - capacidade que os mídias têm decolocar comoalgo importantedeterminado assunto, dando-Ihe não apenas relevância 
quanto hierarquia e significado. Há muitos assuntos que são noticiados constantemente mas que não são conscientizados como centrais (isto é, decisivos) para a nossa vida, enquanto que outros assim se tornam. Por exemplo, a questão do Plano Real e a queda da inflação como um elemento al ternativo de redistribuição de riqueza;

tematização - é o procedimento implicitamenteligado à centralidade, na medida em que se trata da capacidade de dar o destaque necessário (sua formulação, a maneira pela qual o assunto é exposto), de modo a chamar a atenção. Um dos desdobramentos da tematizaçãoéachamadasuítedeumamatéria, ou seja, os múltiplos desdobramentos que a informação vai recebendo, de maneira a manter presa a atenção do receptor naquele assunto;

saliência - valorização individual dada pelo receptor aumdeterminadoassunto noticiado, que setraduz pela percepção que el evenha a emprestar à opinião pública;

focalização - a maneira pela qual a mídia aborda um determinado assunto, apoiandoo, contextualizando-o, assumindo determinadalinguagem, tomandocuidadosespeciais para a sua editoração, inclusive mediante a utilização de chamadas especiais, chapéus, logotipias, etc.

Concluo, chamando a atenção para o fato de que estas hipóteses de trabalho, embora nascidas no âmbito dos estudos da comunicação jornalística, podem ser utilizadas como base para estudos em outros campos da comunicação social, como a publicidade ou as relações públicas. A o menos, esta tem sido a minha experiência, como professor da Cadeira de Teoria da Informação nos cursos de Especialização e M estrado da FAMECOS, nos últimos cinco anos, aproximadamente, desdequeestesestudosforamsugeridospelo professor Jacques Wainberg, Coordenador dos Cursos, que então recém regressava de um estágio nos Estados Unidos. Já temos, hoje, uma série de Dissertações de Mestrado que se valeram dessas diferentes hipóteses detrabal ho, comexcelentes resultados, ainda que a preferência evidente seja pela agendasetting, como se verá pelo conjunto a seguir de ensaios produzidos no âmbito do curso por nossos alunos.

Por outrolado, damesmaformaqueahipótese de agendamento pode ser articulada com as mais diferentes teorias no campo da comunicação social ou mesmo de outras áreas disciplinares, elapodeser também combinada com as demais hipóteses antes mencionadas.Por exemplo, se o agendamento se preocupa com a relação mídia-receptor e as interinfluências desse processo, poderemos aprofundar um estudo, através do newsmaking, verificando quais as rotinas que as mídias desenvolvem para alcançar determinado agendamento. Ou, sob perspectiva diversa, a partir de uma perspectiva de agendamento , buscar entender os mecanismos pelos quais houve uma espiral de silêncio sobre outros tantos temas que, apesar de hipoteticamente significativos, foram marginalizados pelas mídias. Em síntese, as alternativas de trabalho são infinitamente múltiplase, tambémnestecaminhoalgunsde nossos alunos têm-se ensaiado, com bons resultados.

Fica, paraosfuturosnúmeros denossarevista, o compromisso deseabordar, igualmente, as demais hipóteses, a do newsmaking e a da espiral de silêncio, tendo em vista, sobretudo, a escassez de material em língua portuguesa até o momento .

\section{Notas}

1 WOLF, Mauro. Teorias da Comunicação, Lisboa, Presença. 1992.P. 17 ess.

2 RÜDIGER, Francisco. Comunicação e Teoria social moderna, Porto Alegre, Fênix.1995.

3 WOLF, Mauro. Los Efectos sociales de los M edia, Barcelona, 
Paidós.1994 . Registra-se também a tradução integral da obra de NOELLE-NEUMANN, Elisabeth. La Espiral del Silencio - O pinión pública: nuestra piel social, Barcelona, Paidós. 1995.

4 DEBRAY, Régis. Curso de Midiologia geral, Perópolis, Vozes 1993; Vida e M orte da Imagem, Petrópolis, Vozes. 1994.

5 Ver nota 1, p. 157 ess.

6 DE FLEUR, Melvin L. Teorias de Comunicação de M assa, Rio de Janeiro, Zahar.1971.

7 LANG, Gladys Engel et LANG, Kurt. "Watergate: An Exploration of the Agenda-building Process", in WILHOIT, G.C. \& BOCK, H. de (Eds.). M ass Communication Review Yearbook 2 , Beverly Hills, Sage.1981 (ps. 447-468).

8 TARDE, Gabriel. A O pinião e as M assas, S.Paulo, Martins Fontes. 1992.

9 LIPPMANN, Walter. Public Opinion, Nova York, MacMillan. 1922.

10 TÖNNIES, Ferdinand. Comunity and Society, East Lansing, Michigan StateUniversity Press. 1957 (edição alemãoriginal de 1887).

11 Pesquisa interessantepode ser feita a respeito da campanha eleitoral municipal de Porto Alegre em 1996: al guns jornais da capital antecederam, em torno de maio, a campanha eleitoral, indagandodoseleitoressobreseusprincipaistemas de preocupação. Na ocasião, avultou a questão da saúde. Verificou-se, posteriormente, que a maioria dos candidatos terminou por agendar esse tema em seus discursos de campanha.

12 McCOMBS, Maxwell E. and SHAW, Donald L." Theagendasetting function of mass media". In Public O pinion Q uarterly, Vol. 36, N. 2, Summer 1972, Ps. 176-187.

13 SCHRAMM, Wilbur (Ed.). The Process and Effects of M ass Communication , Urbana, University of Illinois Press. 1954.

14 LANE, RobertE. et SEARS, David O. A O pinião pública, Rio de Janeiro, Zahar.1966.

15 SHAW, Donald L. and McCOMBS, Maxwell E. The Emergence of A merican political issues: The Agenda-setting function of the Press, Saint Paul,Minnesotta, West Publishing Co. 1977.

16 McCOMBS,Maxwell ;EINSIEDEL,EdnaetWEAVER,David. Contemporary Public Opinion: Issues and the News, Hillsdale,New Jersey, Lawrence Erlbaum Associates, Publishers.1991.

17 NOELLE-NEUMANN, Elisabeth. "Return to theConcept of Powerful Mass Media", comunicação apresentada no Xxth. International Congress of Psychology, em Tóquio. Agosto de 1972. Publicado posteriormente em Studies of Broadcasting, 9 (1973).

18 BARROS FILHO, Clóvis. Ética na Comunicação: da informação ao receptor, S.Paulo, Moderna.1995.

Cíntia Cavalli

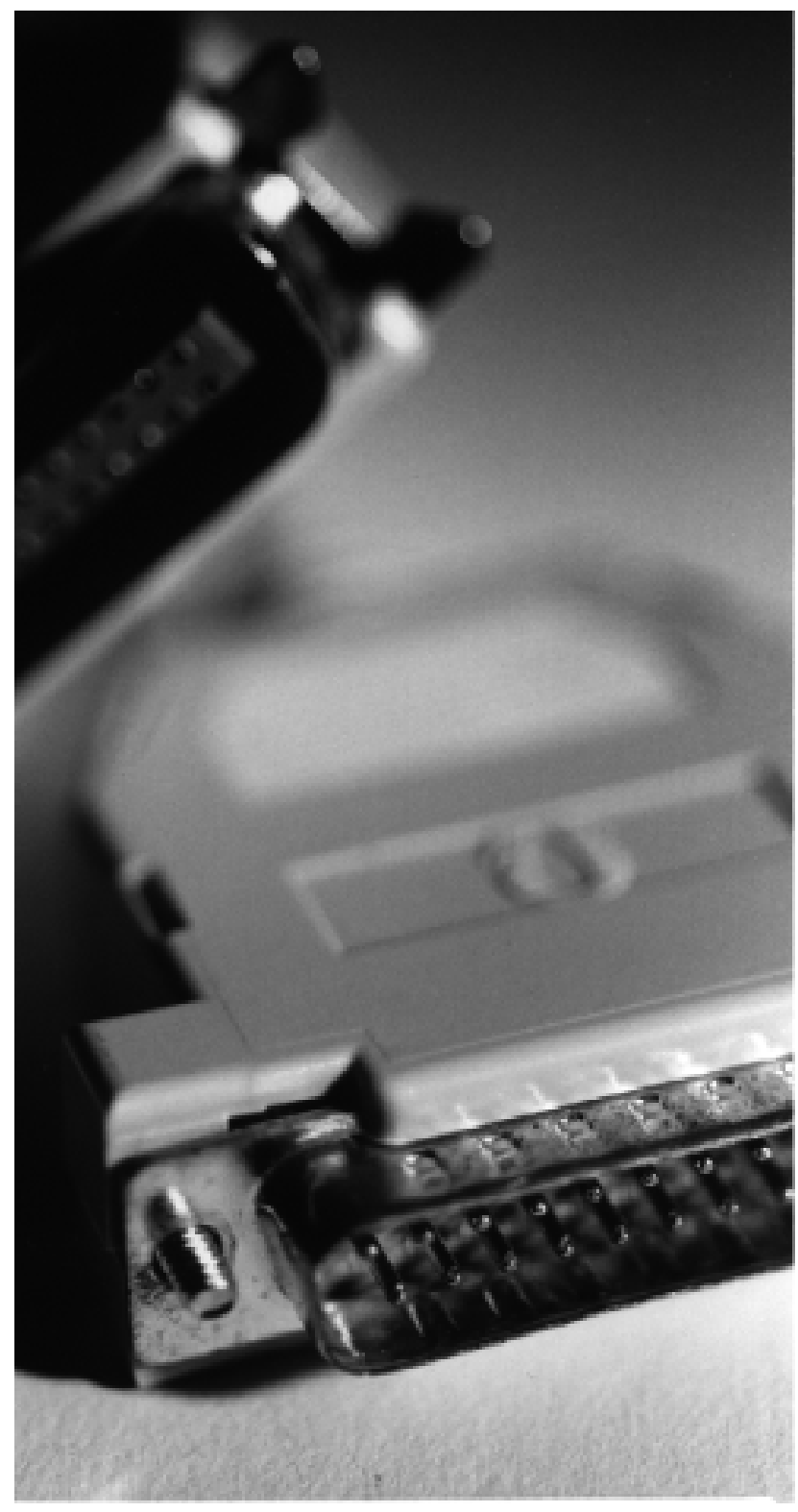

